\title{
Root Residues: Substrates used by Fusarium culmorum to Infect Wheat, Barley and Ryegrass
}

\author{
By ERIC J. GUSSIN AND JAMES M. LYNCH* \\ Agricultural Research Council Letcombe Laboratory, Wantage OX12 9JT, U.K.
}

(Received 4 June 1982; revised 2 August 1982)

\begin{abstract}
Fusarium culmorum was grown on different natural substrates and its subsequent pathogenicity towards wheat, barley and ryegrass studied. This fungus caused more inhibition of plant growth of all test species when grown on root residues than when present as a spore suspension in sand. More wheat seedlings were killed when sown into infected ryegrass root residues than when sown into infected wheat or barley residues. However, when ryegrass was sown into infected ryegrass roots no plant death occurred compared with over $50 \%$ when sown into infected wheat or barley. Dressing ryegrass seeds with a formulation containing calcium peroxide gave some control of $F$. culmorum. These results are discussed in relation to the problems that can sometimes occur following reseeding of grassland.
\end{abstract}

\section{INTRODUCTION}

Establishment problems for a new grass crop can follow direct reseeding. Possible explanations include damage by insects (Clements, 1980), microbiologically produced phytotoxic compounds (Lynch, 1977; Lynch \& Penn, 1980, Gussin \& Lynch, 1981) and soilborne pathogens (Labruyere, 1979). Fusarium culmorum has long been known as a potential pathogen of grasses; Bennett (1935) described its prevalence on British grasses and cereals and Gordon (1952) made similar observations in Canada. More recently Penn \& Lynch (1982) indicated its importance as a pathogen of cereals in the presence of decaying couch grass (Agropyron repens). Following grassland establishment by direct seeding, we have always isolated $F$. culmorum from establishing grasses. However, although the isolates have always been potentially pathogenic the seedlings have not always been affected. The substrate base from which a fungus grows in soil can strongly influence its growth and pathogenicity (Garrett, 1981) and therefore we have investigated the potential of different root residues to act as substrates from which $F$. culmorum may infect wheat, barley and ryegrass.

The potential for calcium peroxide, which has antimicrobial properties (Lynch et al., 1981), as a seed dressing to alleviate $F$. culmorum infection of ryegrass has also been studied.

Because of the variability of soil and the consequential difficulty in designing reproducible experiments, the present study in a controlled environment was performed using sand culture.

\section{METHODS}

Preparation of spore suspensions. Fusarium culmorum (W. G. Smith) Sacc. IMI 239950, was isolated from diseased ryegrass plants and maintained in sterile soil. The fungus was recovered from the soil by inoculating on to potato dextrose agar; spore suspensions were prepared $10 \mathrm{~d}$ later by adding distilled water $(10 \mathrm{ml})$ to each dish and gently brushing the surface with a camel hair brush. This suspension was adjusted to $10^{6}$ spores $\mathrm{ml}^{-1}$ as necessary.

Preparation of infected root materials. Barley (Hordeum vulgare) and wheat (Triticum aestivum) seeds were selected by weight (weight per seed was $35-40$ and $40-45 \mathrm{mg}$, respectively) to decrease plant variability (Harper \& Lynch, 1980). Ryegrass (Lolium perenne, cv. S24) seeds were selected for uniform seed size by eye, with large and small seeds likewise being rejected to decrease variability. Cereal seeds were grown for $9 \mathrm{~d}(5$ plants per jar) and ryegrass for $14 \mathrm{~d}$ (10 plants per jar) in acid washed, coarse sand (particle size $0.5-1.5 \mathrm{~mm}$ diam.) moistened with nutrient solution in $0.5 \mathrm{~kg}$ Kilner jars $(0.41$ capacity); each treatment was replicated four times. Inoculum ( $3 \mathrm{ml})$ of 
a standard spore suspension $\left(10^{6}\right.$ spores $\left.\mathrm{ml}^{-1}\right)$ was added as a drench to each jar immediately after planting. Jars were covered with plastic bags until emergence to maintain high humidity, and the plants were grown in a controlled environment cabinet at $20^{\circ} \mathrm{C}\left( \pm 1{ }^{\circ} \mathrm{C}\right), 75 \%$ relative humidity $( \pm 10 \%)$ and $16 \mathrm{~h}$ photoperiods.

Plant culture solution. All jars were watered daily to maintain their initial weight with a plant culture solution of composition: $1.5 \mathrm{mM}-\mathrm{Ca}\left(\mathrm{NO}_{3}\right)_{2}, 5 \mathrm{mM}-\mathrm{KNO}_{3}, 1 \mathrm{mM}-\mathrm{KH}_{2} \mathrm{PO}_{4}, 1.5 \mathrm{mM}-\mathrm{MgSO}_{4}, 2 \mathrm{mM}-\mathrm{NaNO}_{3}, 0.01 \mathrm{mM}-\mathrm{Fe}^{3+}$ as ferric EDTA, $9 \cdot 2 \mu \mathrm{M}-\mathrm{H}_{3} \mathrm{BO}_{3}, 0.16 \mu \mathrm{M}-\mathrm{CuSO}_{4}, 14 \cdot 1 \mu \mathrm{M}-\mathrm{KCl}, 3.6 \mu \mathrm{M}-\mathrm{MnSO}_{4}, 0.016 \mu \mathrm{M}-\left(\mathrm{NH}_{4}\right)_{6} \mathrm{Mo}_{7} \mathrm{O}_{24}, 0.77 \mu \mathrm{M}-$ $\mathrm{ZnSO}_{4}$.

Reseeding technique. After $9 \mathrm{~d}$ (cereals) or $14 \mathrm{~d}$ (ryegrass), the shoots were removed at seed level (to prevent regrowth) without disturbing the root systems and wheat, barley or ryegrass seeds were 'reseeded' adjacent to the old seeds. Control jars contained uninfected root material or $F$. culmorum only. Ryegrass seeds were planted either undressed or dressed with $20 \%(\mathrm{w} / \mathrm{w})$ of a calcium peroxide formulation bound to the seed with polyvinyl alcohol (Lynch et al., 1981).

Assessment of plant growth and infection. Percentage germination and shoot heights were measured after a further 9 and $14 \mathrm{~d}$ for cereals and ryegrass, respectively. Plants were then taken from the jars and any adhering sand particles removed from the root systems. The longest roots of all plants were measured and were then examined macroscopically for infection and scored on an arbitrary scale such that any plant with lesions greater than $2.5 \mathrm{~mm}$ on one or more roots was recorded as infected. Plants with lesions less than $2.5 \mathrm{~mm}$ on only one root rarely showed any stunting of growth at $28 \mathrm{~d}$.

These lesions were further examined microscopically to confirm infection and $F$. culmorum was reisolated from them on all occasions. Wheat seeds often showed pre-emergence death and these were examined by scanning electron microscopy. Seeds were bisected and fixed in glutaraldehyde $(1 \%$, w/v) for $1 \mathrm{~h}$ followed by glutaraldehyde $(3 \%, \mathrm{w} / \mathrm{v})$ for $24 \mathrm{~h}$. They were then washed in distilled water and dehydrated to $20 \%(\mathrm{v} / \mathrm{v})$ acetone in water. Further dehydration to pure acetone was achieved by dehydration/diffusion under vacuum. They were then dried using a $\mathrm{CO}_{2}$ critical-point dryer.

\section{RESULTS}

The non-inoculated wheat root residues had no effect on germination or root and shoot growth of the cereals but did inhibit root and shoot growth of ryegrass. Both barley and ryegrass noninoculated residues inhibited growth of all test plants but had little effect on germination (Table 1). Fusarium culmorum alone reduced wheat germination by $43 \%$ and severely inhibited root and shoot growth. Germination of barley and ryegrass was not inhibited and, whereas both shoot and root growth of barley were depressed, there was no effect on ryegrass. However, when

Table 1. Effect of plant residues and Fusarium culmorum infection on the germination and root and shoot growth of wheat, barley and ryegrass

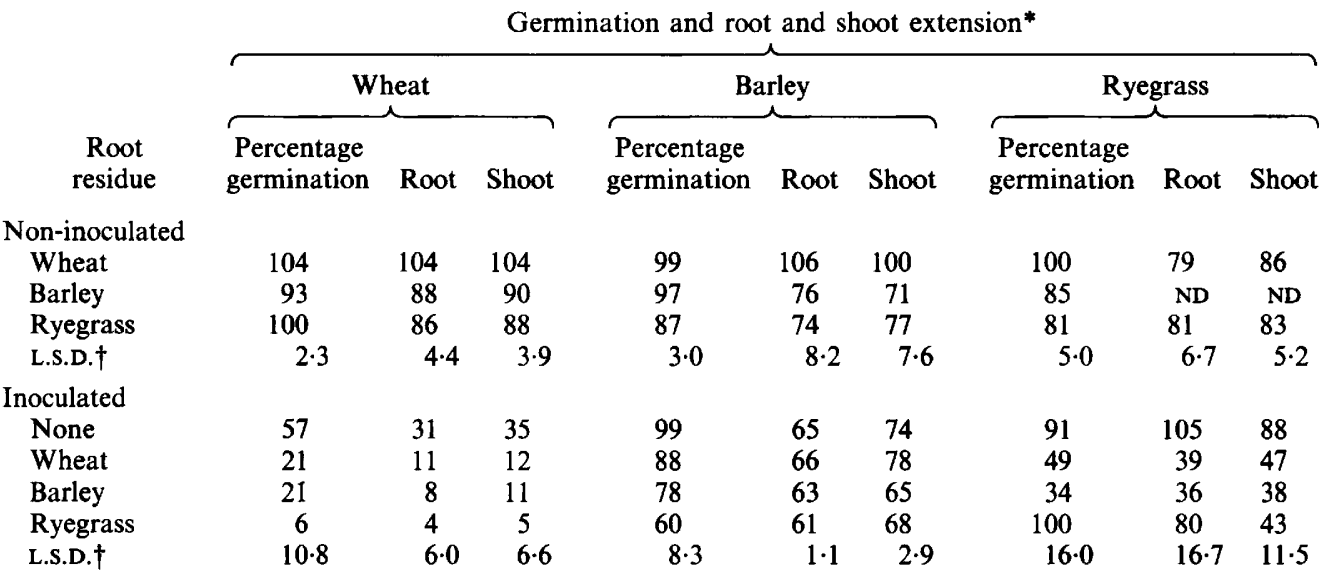

ND, Not determined.

* Percentage of controls where no plant residues or infection were present. Extension was measured as the total root or shoot system.

$\dagger$ Least significant difference $(P=0.05)$. 

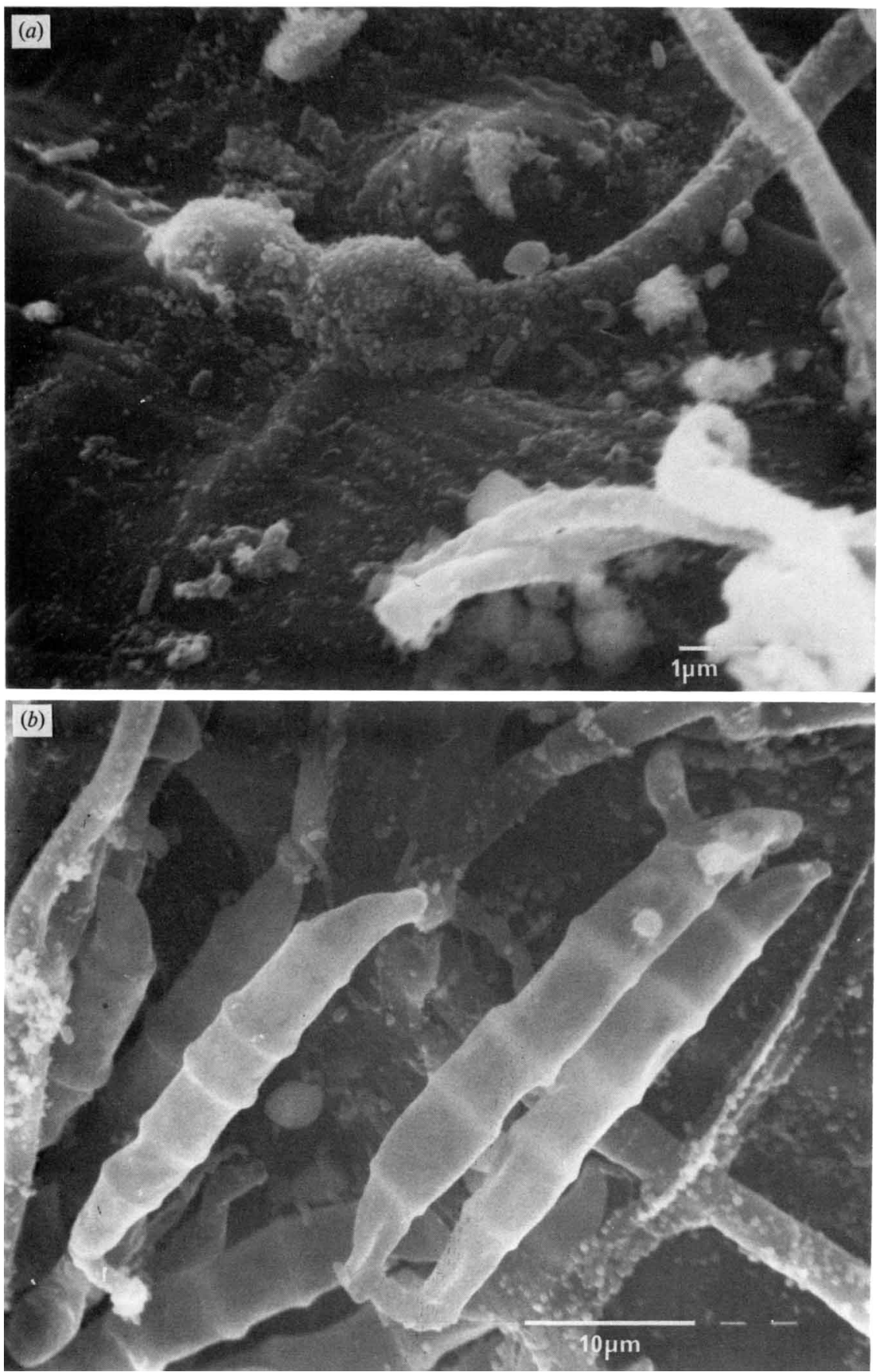

Fig. 1. Scanning electron micrographs of Fusarium culmorum on the wheat seed coat. (a) Appressorium-like structure on cuticle cells. Note the extensive covering of bacteria. (b) Young macroconidia.

infected wheat or barley residues were present as a substrate base for the fungus, germination and root and shoot growth of wheat and ryegrass were strongly inhibited but there was little additional effect on barley. Infected ryegrass residues caused severe inhibition of germination and root and shoot growth of wheat. However, ryegrass residues caused no inhibition of 
Table 2. Degree of infection by Fusarium culmorum as influenced by its growth on wheat, barley or ryegrass root material

$\begin{array}{lccccccc}\text { Root residue } & \overbrace{\text { Infection }}^{\text {Wheat }} & \text { Death } & \overbrace{\text { Infection }}^{\text {Barley }} & \text { Death } & \overbrace{\text { Infection }}^{\text {Rercentage infection and death* }} \\ \text { None } & 100 & 45 & 66 & 6 & 80 & 17 \\ \text { Wheat } & 100 & 66 & 100 & 25 & 92 & 52 \\ \text { Barley } & 95 & 90 & 95 & 25 & 95 & 62 \\ \text { Ryegrass } & 100 & 93 & 72 & 40 & 80 & 0 \\ \text { L.S.D.† } & 1.25 & 11.0 & 8.4 & 7.0 & 3.9 & 12.1\end{array}$

* Both values were zero when $F$. culmorum was not inoculated. Percentage death includes both pre- and postemergence death. Percentage infection includes dead seeds.

$\dagger$ Least significant difference $(P=0.05)$.

Table 3. Response of calcium peroxide-dressed ryegrass seeds to Fusarium culmorum infection

\begin{tabular}{|c|c|c|c|c|c|c|c|c|}
\hline \multirow[b]{3}{*}{ Root residue } & \multicolumn{8}{|c|}{ Germination, root and shoot extension, and infection of ryegrass } \\
\hline & \multicolumn{4}{|c|}{ Undressed seed } & \multicolumn{4}{|c|}{ Dressed seed } \\
\hline & Germination* & $\begin{array}{l}\text { Percentage } \\
\text { infection }\end{array}$ & Root* & Shoot* & Germination* & $\begin{array}{l}\text { Percentage } \\
\text { infection }\end{array}$ & Root* & Shoot* \\
\hline None & 84 & 80 & 80 & 60 & 97 & 75 & 86 & 78 \\
\hline Wheat & 44 & 92 & 39 & 47 & 62 & 83 & 62 & 59 \\
\hline Barley & 32 & 95 & 36 & 32 & 66 & 79 & 67 & 68 \\
\hline Ryegrass & 51 & 80 & 52 & 46 & 67 & 81 & 62 & 66 \\
\hline L.S.D. $\dagger$ & $11 \cdot 0$ & $3 \cdot 9$ & $10 \cdot 0$ & $5 \cdot 7$ & $8 \cdot 1$ & $3 \cdot 4$ & $5 \cdot 7$ & 3.9 \\
\hline
\end{tabular}

* Values are expressed as the percentage of controls when no plant residues or infection were present.

$\dagger$ Least significant difference $(P=0.05)$.

germination of ryegrass and only depressed root growth slightly. Shoot growth was more strongly inhibited. The response from barley to ryegrass residues was intermediate between that of wheat and ryegrass (Table 1 ).

More wheat plants were killed than barley or ryegrass and much of this death was preemergent, seemingly a result of infection via appressoria (Fig. 1). All wheat plants became infected (Table 2). More barley plants died when sown into infected ryegrass residues than when sown into infected wheat or barley residues although fewer seedlings became infected. When ryegrass was sown into infected ryegrass residues, although $80 \%$ became infected, there was no plant death. This contrasts with the $52 \%$ and $62 \%$ plant death observed when sown into wheat and barley, respectively (Table 2).

Dressing ryegrass seeds with calcium peroxide improved plant growth. Germination was improved by $16 \%$ for ryegrass, $18 \%$ for wheat and $34 \%$ for barley. Root and shoot growth was improved in all cases, although there was still some inhibition compared with the control (Table 3 ). The degree of infection by the fungus was slightly decreased, except for the ryegrass residue where there was no effect.

\section{DISCUSSION}

Fusarium foot and root rots often lead to a stunting of plant growth (Fitt \& Hornby, 1978; Weste, 1975; Cook, 1980) and this was the major symptom in this study for barley, whereas for wheat and ryegrass there was up to $90 \%$ and $60 \%$ plant death, respectively. The degree of infection on all three types of root was broadly similar, but barley plants in particular could support an extensive fungal biomass with little obvious effect on the plant. 
The formation of appressoria, which is a normal prerequisite for infection in the fungi that produce them, is often enhanced in the presence of microorganisms, sometimes because the saprophytes deprive the pathogens of nutrients (Lockwood \& Filonow, 1981). The extensive covering of bacteria observed on the appressoria of $F$. culmorum in the present study may reflect this.

At the time of seeding, the root residues were only partially dead with large areas remaining white and turgid with an intact cortex, as shown by light microscopy. The fungus was therefore probably living parastically on the root residue. Cook \& Bruehl (1968) showed that in the soil wheat straws are rarely colonized saprophytically by $F$. culmorum even when large populations are present, but more usually colonization is by the parasitic mode prior to death of the host. This study shows that the nature of the substrate base is important. Sowing ryegrass into infected ryegrass root residue did not lead to any plant death compared with the high death rates when sown into infected wheat and barley residues. It is possible that ryegrass roots may not be a particularly good substrate base for $F$. culmorum under these conditions. In soil, other stress factors acting on both the plant and the microflora will alter the results, and the significance of these results to soil-grown plants needs to be evaluated. The method employed did not allow for standard amounts of substrate to be used in each treatment, but the small variation in these would be unlikely to account for the results obtained.

Calcium peroxide gave some control of the Fusarium damage, although this was usually evident as a reduction in the extent of infection rather than a prevention of infection. This effect could be due to the coating preventing or slowing spore germination. The treatment could have other advantages in the neutralization of phytotoxic organic acids produced by saprophytes and the provision of oxygen when this is limiting (Lynch et al., 1981); its potential for use in soil seems worth evaluating.

We thank Mr S. F. Young for assistance with microscopy and Professor G. F. Pegg for helpful comments. We also thank Imperial Chemical Industries (Plant Protection Division) for financial support of this work.

\section{REFERENCES}

BENNETT, F. T. (1935). Fusarium species on British cereals. Annals of Applied Biology 22, 479-507.

Clements, R. O. (1980). Grassland pests - an unseen enemy. Outlook on Agriculture 10, 219-223.

COOK, R. J. (1980). Fusarium foot rot on wheat and its control in the Pacific Northwest. Plant Diseases 64, 1061-1066.

CoOK, R. J. \& Bruehl, G. W. (1968). Relative significance of parasitism versus saprophytism in colonisation of wheat straw by Fusarium culmorum in the field. Phytopathology 58, 306-308.

FirT, B. D. L. \& HoRNBY, D. (1978). Effects of root infecting fungi on wheat transport processes and growth. Physiological Plant Pathology 13, 335-346.

GARRETT, S. D. (1981). Soil Fungi and Soil Fertility, 2nd edn. Exeter: Pergamon Press.

GORDON, W. L. (1952). Occurrence of Fusarium species in Canada. II. Prevalence and taxonomy of Fusarium species in cereal seed. Canadian Journal of Botany 30, 209-251.

Gussin, E. J. \& LYNCH, J. M. (1981). Microbial fermentation of grass residues to organic acids as a factor in the establishment of new grass swards. New Phytologist 89, 449-457.

HARPER, S. H. T. \& LYNCH, J. M. (1980). Microbial effects on the germination and seedling growth of barley. New Phytologist 84, 473-481.
LABRUYERE, R. E. (1979). Resowing problems of old pastures. In Soil Borne Plant Pathogens, pp. 313-326. Edited by B. Schippers \& H. Gams. London: Academic Press.

Lockwood, J. L. \& Filonow, A. B. (1981). Responses of fungi to nutrient-limiting conditions and to inhibitory substances in natural habitats. Advances in Microbial Ecology 5, 1-61.

LYNCH, J. M. (1977). Phytotoxicity of acetic acid produced in the anaerobic decomposition of wheat straw. Journal of Applied Bacteriology 42, 81-87.

LyNCH, J. M. \& PENN, D. J. (1980). Damage to cereals caused by decaying weed residues. Journal of the Science of Food and Agriculture 31, 321-324.

LYNCH, J. M., HARPER, S. H. T. \& Sladdin, M. (1981). Alleviation, by a formulation containing calcium peroxide and lime, of microbial inhibition of cereal seedling establishment. Current Microbiology 5, 2730.

PenN, D. J. \& LYNCH, J. M. (1982). The effect of bacterial fermentation of couch grass rhizomes and Fusarium culmorum on the growth of barley seedlings. Plant Pathology 31, 39-45.

WESTE, G. (1975). Comparative pathogenicity of root parasites to wheat seedlings. Transactions of the British Mycological Society 64, 43-53. 